Doi: $\underline{\text { dx.doi.org/10.17921/2525-5320.2016.301-302 }}$

\title{
A ABORDAGEM HISTÓRICA DA PERSPECTIVA CTS NO BRASIL
}

\author{
Clarice Sanches Mariante Hirakuri* - UNOPAR \\ Andréia de Freitas Zompero* - UNOPAR
}

Palavras-chave: Abordagem Histórica. Perspectiva CTS. Ensino no Brasil.

\section{INTRODUÇÃO}

Neste estudo tivemos o intuito de analisar a perspectiva CTS - Ciência, Tecnologia e Sociedade, em alguns dos documentos oficias de ensino no Brasil. Assim, nesta análise e também de acordo com Pinheiro, Silveira e Bazzo (2007), que o ensino na educação científica passará a ser entendido como a possibilidade de despertar no aluno a curiosidade, o espírito investigador, questionador e transformador da realidade.

\section{MATERIAL E MÉTODOS}

A pesquisa realizada é do tipo documental, para a qual foi feito um levantamento dos documentos oficiais de ensino da educação brasileira, são eles o Parâmetros Curriculares Nacionais Ciências da Natureza, Matemática e Tecnologia (PCN+,2002), Diretrizes Curriculares Estaduais do estado do Paraná (DCE,2008) e o Pacto Nacional pelo fortalecimento do Ensino Médio (2014). A comparação entre os documentos tem o intuito de estabelecer uma breve análise sobre a proposta de implementação dado ao enfoque CTS (Ciência, Tecnologia e Sociedade) na Educação Básica, traçar um perfil histórico, assim como a possível utilização em salas de aula. A abordagem da pesquisa é do tipo qualitativa por considerar "O universo de significados, motivos, aspirações crenças, valores e atitudes, o que corresponde a um espaço mais profundo das relações, dos processos e dos fenômenos que não podem ser reduzidos à operacionalização de variáveis". (MINAYO, 1994, p.22).

\footnotetext{
*E-mail: claricesanches@uol.com.br *E-mail: andzomp@yahoo.com.br
} 


\section{RESULTADOS E DISCUSSÃO}

Após as análises dos documentos e leituras de autores destacados, concordamos com o recorte de Santos e Mortiner,2002, e cita que os trabalhos curriculares em CTS surgiram, como que em decorrência da necessidade de formar o cidadão para as ciências e para a tecnologia, o que ainda não era alcançado adequadamente pelo ensino convencional de Ciências.

\section{CONCLUSÃO}

Consideramos que os documentos de ensino, estão alinhados com as propostas curriculares apontadas por autores na literatura nacional e internacional quanto à educação científica. Além disso, ressaltam a necessidade e possibilidades de mudança curricular com ênfase na CTS, visando formação crítica.

\section{REFERÊNCIAS}

BRASIL. Ministério da Educação. Pacto Nacional pelo Fortalecimento do Ensino Médio. Brasília: MEC, 2014.

BRASIL. Parâmetros Curriculares Nacionais (Ensino Médio) - Parte III - Ciências da Natureza, Matemática e suas Tecnologias. Brasília: MEC, 2002.

MINAYO, C.S. Pesquisa social: teoria, método e criatividade. Petrópolis: Vozes,1994.

PARANÁ. Secretaria de Estado da Educação. Diretrizes curriculares da Educação Básica: Ciências. Curitiba, 2002.

PARANÁ. Secretaria de Estado da Educação. Diretrizes curriculares da Educação Básica: Biologia. Curitiba, 2008.

PINHEIRO, N.A.; SILVEIRA, R.M.; BAZZO, W.A. A relevância do enfoque CTS para o contexto do ensino médio. Ciênc. Educ., v.13, n.1, p.71-84, 2007 